\title{
ANALISIS POTENSI DAYA TARIK WISATA GASTRONOMI DI KAWASAN PETAK SEMBILAN GLODOK, JAKARTA BARAT
}

\author{
Susy Bhudiharty ${ }^{1}$, Kania Ratnasari², Sihono Dwi Waluyo ${ }^{3}$ \\ Fakultas Ekonomi dan Bisnis, Universitas Sahid \\ Jl. Soepomo No 84, Jakarta Selatan \\ Email Korespondensi: kania.ratnasari@yahoo.com
}

\begin{abstract}
ABSTRAK
Kota Jakarta tidak hanya sebagai Ibukota Negara Republik Indonesia tetapi juga merupakan destinasi tujuan wisata. Salah satu destinasi yang ramai dikunjungi oleh wisatawan adalah kawasan Kota Tua di Jakarta yang juga adalah salah satu dari 10 Destinasi Prioritas Nasional. Kota Tua Jakarta selain terkenal dengan wisata sejarah juga terkenal dengan wisata kuliner. Wisata kuliner di Kota Tua dipengaruhi oleh budaya Cina karena memang area ini merupakan daerah pecinan. Wisata kuliner sekarang ini menjadi ikon wisata karena ada jenis wisatawan yang datang ke sebuah destinasi untuk menikmati kulinernya. Wisata kuliner adalah jika wisatawan yang datang ke sebuah destinasi wisata bertujuan untuk menikmati makanan tradisional, namun jika wisatawan datang ke sebuah destinasi untuk ikut proses persiapan hingga penyajian dikenal dengan istilah wisata gastronomi. Tujuan penelitian ini adalah untuk mengetahui daya tarik wisata gastronomi apa saja yang ada di Petak Sembilan. Penelitian ini menggunakan metodologi analisis deskriptif. Hasil penelitian adalah terdapat tiga potensi daya tarik wisata gastronomi di Kawasan Petak Sembilan Glodok, Jakarta Barat yaitu Gado-Gado Direksi, Pantjoran Tea House and Kopi Takkie. Di tempat ini wisatawan bisa melihat, mengikuti dan mencoba proses pembuatan makanan sambil mendengarkan cerita tentang sejarah tea tersebut dan tentunya setelah proses tersebut menikmati minumnya. Kawasan Kota Tua memiliki potensi menjadi destinasi wisata gastronomi di Jakarta.
\end{abstract}

Kata Kunci: Jakarta, Kota Tua, Petak Sembilan, Gastronomi

\begin{abstract}
The city of Jakarta is not only the Capital of the Republic of Indonesia but also a tourist destination. One of the destinations visited by tourists is the Old City area in Jakarta, which is also one of the 10 National Priority Destinations besides being famous for its historical tourism, it is also famous for culinary tourism. Culinary tourism in the old city is influenced by Chinese culture because it is indeed an area. Culinary tourism is now a tourist icon because there are types of tourists who come to a destination to enjoy their culinary. The purpose of this study is to find out what gastronomic attractions are in Petak Sembilan. This research uses descriptive analysis methodology. The results of this research are four potential gastronomic attractions in the Kawasan Petak Sembilan, West Jakarta, which are Gado-Gado Direksi, Pantjoran Tea House and Kopi Takkie. In these three places tourists can see, follow and try the process of making food while listening to the stories about the food and beverage. Of course after the process tourists can enjoying the food. Kawasan Kota Tua has potential to become a gastronomic tourist destination in Jakarta
\end{abstract}

Keywords: Jakarta, Old Town, Petak Sembilan, Gastronomic 


\section{PENDAHULUAN}

Kota Jakarta adalah ibukota negara Republik Indonesia yang juga merupakan destinasi tujuan wisata. Salah satu tempat yang dikunjungi oleh wisatawan adalah Kawasan Kota Tua yang berada di Jakarta Barat. Kawasan ini juga merupakan salah satu dari 10 Destinasi Prioritas Nasional yang dicanangkan oleh Kementerian Pariwisata Republik Indonesia. Di bawah ini dapat dilihat jumlah kunjungan wisatawan yang berkunjung ke jakarta dari tahun 2013 hingga 2016.

Table 1. Jumlah Kunjungan Wisatawan ke Jakarta

\begin{tabular}{|c|c|c|}
\hline No. & Tahun & Jumlah \\
\hline 1. & 2013 & 2.125 .513 \\
\hline 2. & 2014 & 2.319 .295 \\
\hline 3. & 2015 & 2.377 .226 \\
\hline 4. & 2016 & 4.085 .969 \\
\hline
\end{tabular}

Sumber: BPS DKI Jakarta, 2018

Data tersebut memperlihatkan jumlah kunjungan yang selalu meningkat dari tahun ke tahun walaupun jumlahnya belum banyak. Namun memberikan harapan yan baik ke depannya. Kawasan kota tua terdiri dari beberapa objek wisata yaitu Museum Fatahilah, Museum Wayang, Museum Bank Mandiri dan banyak lainnya. Penelitian ini akan melihat sisi lain dari wisata kota tua yaitu potensi wisata gastronomi yang bisa menjadi embrio dari wisata gastronomi. Menurut pendapat Brillat-Savarin (1994:52):1) Wisata gastronomi adalah cara untuk melakukan pelestarian kebudayaan melalui pelestarian yang dilakukan oleh manusia melalui makanan, 2) Objeknya adalah memberikan bimbingan, menurut prinsip-prinsip tertentu, untuk semua orang yang mencari, menyediakan, atau menyiapkan makanan 3) Wisata gastronomi memberikan kekuatan ekonomi bagi petani, peternak, nelayan, industri yang terkait dengan penyediaan jasa makanan. Sementara itu pendapat dari Antón Clave dan Knafou (2012: 4) karakteristik wisata gastronomi: 1) Gastronomi sebagai unsur dan indikator globalisasi; khususnya, penegasan kompetisi daerah pada seluruh dunia 2) Wisatawan memberikan peran dalam evolusi wisata gastronomi 3) Pariwisata sebagai pengungkap potensi Gastronomi regional atau lokal dan sebagai kontributor mengembangkan atau memperbaharui identitas nasional dan subnasional 4) Wisata gastronomi sebagai sarana mengenalkan produk kuliner sebagai produk budaya 5) Evolusi wisata gastronomi memberikan arah pengembangan pariwisata 6) Gastronomi sebagai elemen konstruktif dalam pembentukan citra sebuah destinasi wisata 7) Gastronomi sebagai tujuan perjalanan wisata 8) Gastronomi sebagai unsur warisan dengan dimensi wisata. Salah satu kawasan yang mempunyai otentik kuliner tersebut adalah Kawasan Petak Sembilan. Disini banyak sekali ditemukan jenis kuliner peranakan seperti warung kopi, kedai minum teh, warung gado-gado dan lainnya. Keunikan kuliner ini bisa dinikmati oleh wisatawan yang berkunjung ke kawasan ini sambal mendengarkan sejarah tentang kawasan petak sembilam dan tentunya sejarah dari masing-masing produk kuliner tersebut. 
Menurut Global Report and Food Tourism (2012), wisata kuliner adalah segmen industri kuliner yang sedang berkembang pesat, oleh karenanya, pelaku industri wisata di setiap negara harus memahami pentingnya perkembangan wisata kuliner dalam skala lokal, regional, dan nasional (UNWTO, 2012). Di sisi lain, kuliner memegang peranan penting dalam meningkatkan daya tarik wisata; meningkatkan jumlah wisatawan; meningkatkan pengalaman wisatawan; memperkuat identitas daerah; dan stimulasi pertumbuhan sektor lainnya. Sangat jelas bahwa kuliner menyumbang pengaruh berkesinambungan terhadap tujuan wisata.. Seperti yang sudah diulas diatas maka akan dilakukan penelitian tentang ANALISIS POTENSI DAYA TARIK WISATA GASTRONOMI DI KAWASAN PETAK SEMBILAN GLODOK, JAKARTA BARAT. Penelitian akan melihat beberapa wisata kuliner yang berpotensi menjadi wisata gastronomi di Kawasan Petak Sembilan. Adapun rumusan masalah penelitian ini adalah:

Analisis potensi daya tarik wisata gastronomi di Kawasana Petak Sembilan Glodok, Jakarta Barat. Tujuan penelitian adalah untuk mengetahui potensi wisata gastronomi di Kawasan Petak Sembilan Glodok, Jakarta Barat.

\section{METODE PENELITIAN}

Sumber data primer adalah pelaku yang terlibat langsung dengan karakter yang diteliti sedangkan sumber data sekunder adalah karakter hasil liputan lain. Untuk lebih jelasnya mengenai data dan sumber data yang dipergunakan dalam penelitian ini, maka dikumpulkan dan disajikannya berupa data tingkat kunjungan wisatawan ke Jakarta. Teknik pengumpulan data yang digunakan adalah:

1. Studi literatur

Studi literatur adalah usaha untuk menggunakan informasi yang berhubungan dengan teori-teori dan ada kaitannya dengan masalah dan variabel-variabel yang diteliti yang terdiri dari wisata gastronomi.

2. Wawancara atau Interview

Yaitu digunakan untuk memperoleh data dengan cara berkomnikasi secara langsung dengan responden yang terpilih melalui daftar pertanyaan yang sudah disiapkan sebelumnya sebagai pedoman wawancara.

3. Observasi

Observasi dilakukan dengan meninjau serta melakukan pengamatan langsung terhadap objek yang diteliti yaitu Kota Tua Jakarta, khususnya mengenai wisata gastronomi di kawasan Petak Sembilan.

Populasi dalam penelitian ini adalah pemilik rumah makan dan restoran yang ada di Kawasan Petak Sembilan. Karena jumlah rumah makan banyak dan tidak mungkin didatangi satu persatu maka penelitian menggunakan sampel yaitu restoran yang mengizinkan pengunjungnya untuk menyaksikan proses pengolahan makanan dan pemilik atau juru masak bisa bercerita tentang proses yang dilakukan serta sejarah yang tersimpan dibalik makanan tersebut. Operasional Variabel dari penelitian ini adalah: 
Tabel 2. Operasional Variabel Penelitan

\begin{tabular}{|l|l|}
\hline No. & \multicolumn{1}{|c|}{ Varibel Operasional } \\
\hline 1. & $\begin{array}{l}\text { Gastronomi sebagai unsur indikator globalisasi khususnya penegasan kompetisis } \\
\text { daerah di seluruh dunia }\end{array}$ \\
\hline 2. & Wisatawan memberikan peran dalam evolusi wisata gastronomi \\
\hline 3. & $\begin{array}{l}\text { Pariwisata sebagai pengungkap potensi Gastronomi regional atau lokal dan } \\
\text { sebagai kontributor mengembangkan atau memperbaharui identitas nasional dan } \\
\text { subnasional }\end{array}$ \\
\hline 4. & $\begin{array}{l}\text { Pariwisata sebagai pengungkap potensi Gastronomi regional atau lokal dan } \\
\text { sebagai kontributor mengembangkan atau memperbaharui identitas nasional dan } \\
\text { subnasional }\end{array}$ \\
\hline 5. & $\begin{array}{l}\text { Wisata gastronomi sebagai sarana mengenalkan produk kuliner sebagai produk } \\
\text { budaya }\end{array}$ \\
\hline 6. & $\begin{array}{l}\text { Gastronomi sebagai elemen konstruktif dalam pembentukan citra sebuah } \\
\text { destinasi wisata }\end{array}$ \\
\hline 7. & Gastronomi sebagai tujuan perjalanan wisata \\
\hline 8. & Gastronomi sebagai unsur warisan dengan dimensi wisata \\
\hline
\end{tabular}

Sumber: Brillat-Savarin, 1994

Penelitian ini akan menggunakan metode analisis deskriptif yang akan menguraikan hasil observasi dan wawancara dengan pemilik tempat makan/minum di Kawasan Petak Sembilan.

\section{HASIL DAN PEMBAHASAN}

Setelah dilakukan observasi dan wawancara terhadap beberapa rumah makan dan warung minum yang potensial sebagai destinasi wisata gastronomi di kawasan Petak Sembilan ini. Maka diputuskan melalui wawancara dengan 3 (tiga) rumah makan dan minum di Kawasan Petak Sembilan yang yang terpilih yaitu dari Warung Gado-Gado Direksi, Pantjoran Tea House dan Warung Kopi Takkie. Ketiga jenis kuliner tersebut memiliki sejarah yang panjang dari pertama kali berdiri hingga masih bertahan saat ini. Pengunjung dapat menyaksikan proses pembuatan makanan dan minuman ini sambil mendengarkan pemilik bertutur tentang produk kuliner yang mereka sajikan. Warung gado-gado Direksi merupakan warung milik Giok Lie, berawal dari tahun 1967 saat Sinta Dewi (Sie Man Tjauw) yang merupakan saudaranya pertama kali berjualan gadogado di Gang Gloria, Pinangsia yang sekarang berubah jadi Jalan Pintu Besar Selatan II. Saat itu banyak para direktur bank ternama yang berkantor di kawasan Pinangsia dan para direktur yang kerap makan di warung ini sehingga nama warung gado-gado ini lebih dikenal dengan nama gado-gado direksi. Pantjoran Tea House merupakan rumah tempat minum teh yang memiliki cerita tentang kawasan ini cukup lekat dengan kisah kemurahan hati seorang Kapitan Cina bernama Gan Djie dan istrinya. Setiap harinya, pasangan ini menyediakan delapan teko teh di depan kantor Kapitan yang kerap menjadi tempat singgah para pedagang keliling yang kelelahan. Air teh itu bisa diminum tanpa dipungut biaya. Lama kelamaan, penyediaan teh dalam delapan teko teh itu menjadi 
petunjuk utama bagi warga yang mencari kantor Kapitan di kawasan Pecinan. Kawasan ini pun kemudian dikenal sebagai Patekoan, yang dalam bahasa Tiongkok Pa berarti delapan dan Te-Koan berarti teko teh. Salah satu bangunan yang menjadi landmark di kawasan Glodok/Pecinan, yang sudah berdiri sejak tahun 1635, adalah sebuah toko obat tertua kedua di Jakarta (d/h Batavia) yang didirikan sekitar tahun 1928, dikenal sebagai Apotheek Chung Hwa. Untuk mendukung upaya pemerintah menjadikan kawasan Kota Tua Jakarta sebagai situs warisan budaya dunia oleh UNESCO, bangunan ini direvitalisasi pada tahun 2015 oleh arsitek Ahmad Djuhara, dan beralih fungsi menjadi kedai teh dengan nama Pantjoran Tea House. Budaya minum teh di kawasan Pecinan sangat kuat pada saat itu. Bibit teh pertama dibawa dari Jepang oleh seorang botanis bernama Andreas Cleyer dengan kapal VOC yang biasanya berlabuh di sekitar Kota Tua Jakarta. Kedai Kopi Es Tak Kie, yang berlokasi di Gang Gloria, Jalan Pintu Besar Selatan III Glodok Jakarta Barat sudah berusia 90 tahun. Didirikan oleh Liong Kwie Tjong seorang perantau dari China pada tahun 1927. Saat ini, pemiliknya merupakan generasi ketiga bernama Ayauw. Ia meneruskan usaha kakek dan ayahnya sejak 1976. Tempatnya agak sulit ditemukan karena berada di gang sempit yang tidak kelihatan dari jalan besar sebab tertutup mobil yang terparkir disepanjang jalan.

Dari ketiga kuliner di atas, setelah dilakukan observasi dan wawancara sesuai dengan operasional variabel penelitian ini, maka ketiga daya tarik wisata kuliner yang ada di Kawasan Petak Sembilan mempunyai potensi menjadi wisata gastronomi. Pemetaan berdasarkan operasional variabel dapat dilihat pada tabel di bawah ini:

Tabel 3. Hasil Penelitian

\begin{tabular}{|l|l|c|c|c|}
\hline No. & Variabel Operasional & $\begin{array}{c}\text { Gado-Gado } \\
\text { Direksi }\end{array}$ & $\begin{array}{c}\text { Pantjoran Tea } \\
\text { House }\end{array}$ & Kopi Takkie \\
\hline 1. & $\begin{array}{l}\text { Gastronomi sebagai unsur } \\
\text { indikator globalisasi } \\
\text { khususnya penegasan } \\
\text { kompetisis daerah di } \\
\text { seluruh dunia }\end{array}$ & $\vee$ & $\vee$ & $\vee$ \\
\hline 2. & $\begin{array}{l}\text { Wisatawan memberikan } \\
\text { peran dalam evolusi wisata } \\
\text { gastronomi }\end{array}$ & $\vee$ & $\vee$ & $\vee$ \\
\hline 3. & $\begin{array}{l}\text { Pariwisata sebagai } \\
\text { pengungkap potensi } \\
\text { Gastronomi regional atau } \\
\text { lokal dan sebagai } \\
\text { kontributor } \\
\text { mengembangkan atau } \\
\text { memperbaharui identitas } \\
\text { nasional dan subnasional }\end{array}$ & $\vee$ & $\vee$ & $\vee$ \\
\hline 4. & $\begin{array}{l}\text { Wisata gastronomi sebagai } \\
\text { sarana mengenalkan produk } \\
\text { kuliner sebagai produk } \\
\text { budaya }\end{array}$ & & & \\
\hline 5. & & & & \\
Evolusi wisata gastronomi & & $\vee$ & & $\vee$ \\
\hline
\end{tabular}




\begin{tabular}{|l|l|c|c|c|}
\hline No. & Variabel Operasional & $\begin{array}{c}\text { Gado-Gado } \\
\text { Direksi }\end{array}$ & $\begin{array}{c}\text { Pantjoran Tea } \\
\text { House }\end{array}$ & Kopi Takkie \\
\hline & $\begin{array}{l}\text { memberikan arah } \\
\text { pengembangan pariwisata }\end{array}$ & & & \\
\hline 6. & $\begin{array}{l}\text { Gastronomi sebagai elemen } \\
\text { konstruktif dalam } \\
\text { pembentukan citra sebuah } \\
\text { destinasi wisata }\end{array}$ & $\vee$ & $\vee$ & $\vee$ \\
\hline 7. & $\begin{array}{l}\text { Gastronomi sebagai tujuan } \\
\text { perjalanan wisata }\end{array}$ & $\vee$ & $\vee$ & $\vee$ \\
\hline 8. & $\begin{array}{l}\text { Gastronomi sebagai unsur } \\
\text { warisan dengan dimensi } \\
\text { wisata }\end{array}$ & $\vee$ & $\vee$ & \\
\hline
\end{tabular}

Sumber: Brillat-Savarin, 1994

Pada indikator, gastronomi sebagai unsur indikator globalisasi khususnya penegasan kompetisis daerah di seluruh dunia: Gado-gado Direksi, Pantjoran Tea House dan Kopi Takkie memenuhi aspek ini karena ketiga kjenis kuliner ini merupakan kuliner yang sudah dikenal dari dulu dan masih teteap eksis hingga saat ini, mempunyai konsumen yang beragam dari generasi senior hingga anak-anak milineal. Lokasi kuliner ini pun berada di Kawasan Kota Tua yang merupakan destinasi prioritas nasional yang mempunyai nilai sejarah yang tinggi.

Indikator kedua wisatawan memberikan peran dalam evolusi wisata gastronomi; sesuai dengan perkembangan pariwisata tiga kuliner yang sebelumnya hanya merupakan tempat makan dan minum akhirnya sesuai dengan tren bisa dikembangkan menjadi destinasi wisata gastronomi dimana wisatawan yang akan makan atau minum disana tidak hanya menikmati kulinernya saja tetapi juga bisa menambah pengetahuan tentang kuliner dan kawasan tersebut dari nara sumbernya. Indikator ketiga pariwisata sebagai pengungkap potensi gastronomi regional atau lokal dan sebagai kontributor mengembangkan atau memperbaharui identitas nasional dan sub nasional. Indikator ini sangat didukung oleh Kementerian Pariwisata Republik Indonesia yang saat ini sangat peduli pada perkembangan gastronomi dan destinasinya. Indikator ke empat adalah wisata gastronomi sebagai sarana mengenalkan produk kuliner sebagai produk budaya. Wisata kuliner merupakan bagian dari wisata budaya. Kuliner sebuah bangsa mencerminkan budayanya. Pada kuliner yang ada di Kawasan Petak Sembilan ini merupakan bagian dari sejarah peradaban yang ada di kota Batavia pada masa itu. Sementara indikator ke lima yaitu evolusi wisata gastronomi memberikan arah pengembangan pariwisata, Gado-gado direksi, Pantjoran Tea House dan Kopi Takkie merupakan kuliner yang ada di kawasan ini dan bisa berevolusi menjadi wisata gastronomi karena mempunyai aspek untuk bisa dikembangkan.

Gastronomi sebagai elemen konstruktif dalam pembentukan citra sebuah destinasi wisata merupakan elemen ke enam yang sangat memberikan pengaruh yang baik bagi pengembangan wisata kuliner menjadi wisata gastronomi. Elemen ke enam ini merupakan elemen yang sangat perlu dan penting bagi kawasan petak Sembilan, kota tua Jakarta karena selama ini kawasan ini hanya dkenal sebagai tujuan wisata sejarah dan kuliner saja. Jika elemen konstruktif dalam pembentukan citra sebuah destinasi 
wisata ini berhasil maka menambah destinasi wisata gastronomi di kota Jakarta yang wajib dikunjungi oleh para wisatawan sehingga gastronomi sebagai tujuan perjalanan wisata mereka. Gastronomi sebagai unsur warisan dengan dimensi wisata merupakan indikator terakhir dari terbentuk sebuah destinasi wisata gastronomi. Semua indikator sangat sesuai dengan pengembangan wisata gastronomi di kawasan. Hasil analisa dari penelitian yang sudah dilakukan dengan menggunakan semua indikator pada tiga macam kuliner tersebut sangat cocok untuk dikembangakan sebagai destinasi wisata gastronomi. Di bawah ini ada beberapa foto dari ketiga macam jenis kuliner tersebut.

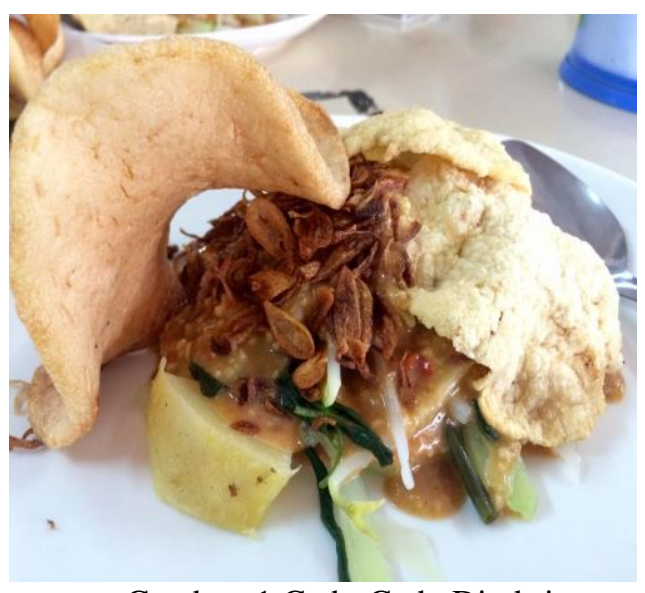

Gambar 1 Gado-Gado Direksi Sumber: Pribadi

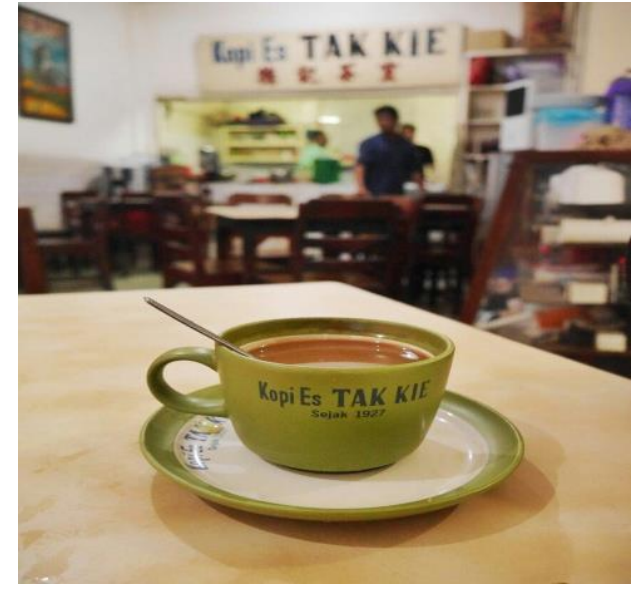

Gambar 2 Kopi Tak Kie Sumber: Situs Kopi Tak Kie, 2018

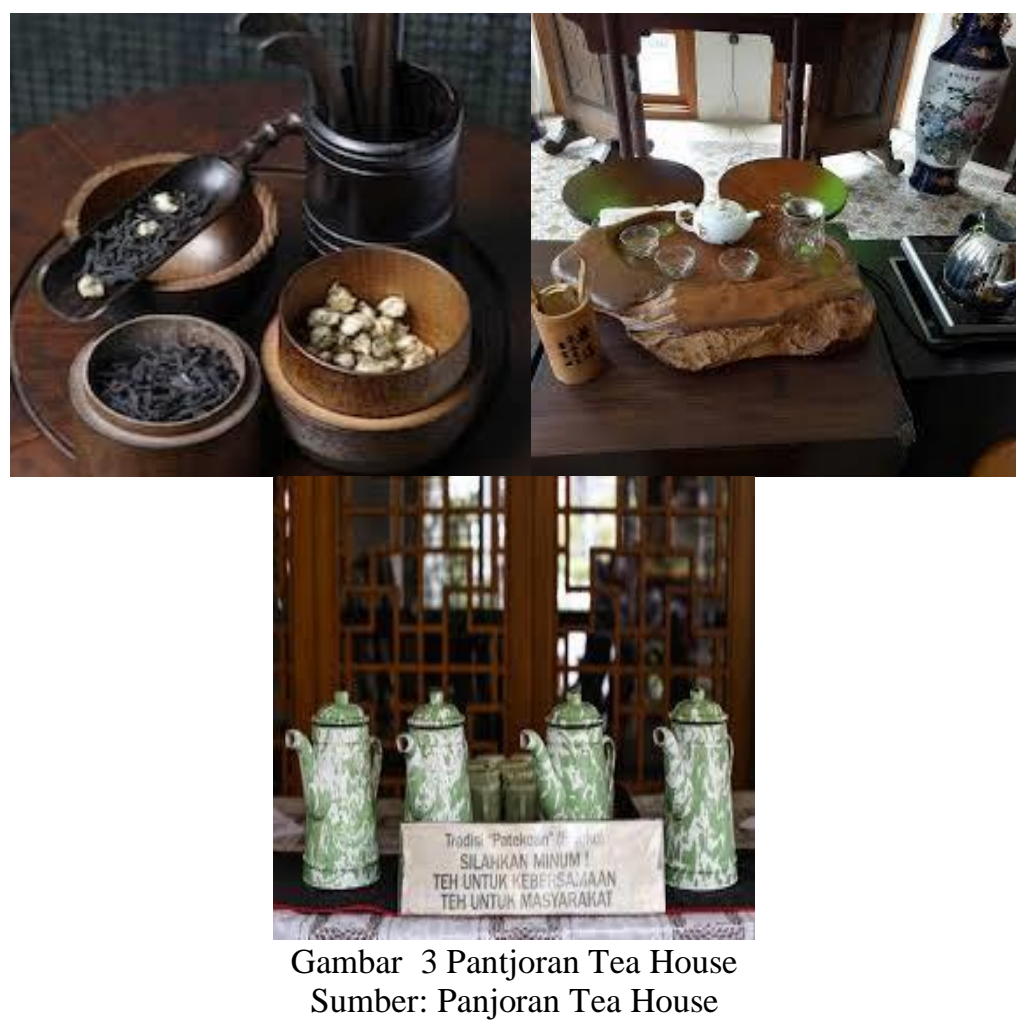




\section{KESIMPULAN DAN SARAN}

Kawasan Petak Sembilan memiliki potensi kuliner yang bisa dijadikan destinasi wisata gastronomi. Tiga tempat yang mempunyai potensi untuk dikembangkan adalah Gado-Gado Direksi, Pantjoran Tea House dan Kopi Tak Kie. Hal ini akan memberikan keuntungan yang sangat baik bagi pariwisata Jakarta khususnya Kawasan Kota Tua. Pantjoran Tea House adalah kuliner yang sangat siap dijadikan sebagai wisata gastronomi, dilihat dari bangunannya yang antik, penutur yang sangat menguasai berbagai cerita dan sejarah dibalik warung ini. Hal yang perlu diperhatikan adalah prihal higienis dan sanitasi dimulai dari tempat, peralatan makan minum dan proses pembuatan.

\section{DAFTAR PUSTAKA}

Antón C, S \& Knafou, R. (2012). Gastronomy Tourism and globalization. Paris: Universitat Rovira i Virgili Tarra gona, Université Paris

Brillat-Savarin, J.-A. (1994). The Physiology of Taste. (Penerjemah: A. Drayton, Harmondsworth: Penguin.

Steinmetz, R (2010). Food, Tourism and Destination Differentiation. The case of Roturua, New Zealand. New Zealand: Auckland University of Technology

Undang-Undang No. 10 Tahun 2009. Kementerian Pariwisata Republik Indonesia. Jakarta

World Tourism Organization. (2012). Global Report on Food Tourism. Madrid: UNWTO. 